\title{
Molecular control of the floral transition in the mast seeding plant Celmisia lyallii (Asteraceae)
}

\author{
Samarth Samarth ${ }^{1}$, Robyn Lee ${ }^{2}$, Dave Kelly ${ }^{1}$, Matthew Turnbull ${ }^{1}$, Richard Macknight ${ }^{2}$, \\ Anthony Poole ${ }^{3}$, and Paula Jameson ${ }^{1}$ \\ ${ }^{1}$ University of Canterbury \\ ${ }^{2}$ University of Otago \\ ${ }^{3}$ The University of Auckland
}

May 28, 2020

\begin{abstract}
Mast flowering (or masting) is synchronous highly variable flowering among years in populations of perennial plants. Despite having widespread consequences for seed consumers, endangered fauna and human health, masting is hard to predict because the underlying mechanism regulating masting is poorly understood. Observational studies show links to various weather patterns in different plant species, but the molecular mechanism(s) underpinning the regulation of masting is still not fully explained. We studied floral induction in Celmisia lyallii (Asteraceae), a mast flowering herbaceous alpine perennial, comparing gene expression in flowering and non-flowering plants. Differential expression analysis showed elevated expression of ClSOC1 and ClmiR172 (promoters of flowering) in leaves of plants that subsequently flowered, in contrast to elevated expression of ClAFT and ClTOE1 (repressors of flowering) in leaves of plants that did not flower. The warm summer temperatures that promoted flowering led to differential regulation of age and hormonal pathway genes, including ClmiR172 and ClGA20ox2/8, known to repress the expression of floral repressors and permit flowering. Upregulated expression of epigenetic modifiers of floral promoters also suggests that plants may maintain a novel 'summer memory' across the years to induce flowering. These results provide a mechanistic understanding of floral induction in masting plants and evidence of their ability to imprint various environmental cues to synchronise flowering. This should allow better prediction of masting events under climate change, thereby assisting conservation programs for the protection of endangered fauna.
\end{abstract}

\section{Hosted file}

Celmisia_Mol Ecol_final_v1.doc available at https://authorea.com/users/326262/articles/ 454147-molecular-control-of-the-floral-transition-in-the-mast-seeding-plant-celmisialyallii-asteraceae 